\title{
Manurial Value and Pollution Abetment of Effluent and Sludge from Biogas Digester Run on Ipomoe Weed and Distillery Waste.
}

\author{
Dr. H.V. Deshmukh. \\ Department of Microbiology. \\ Yashawantrao Chavan Institute of Science, Satara. 415001, Maharashtra. (India)
}

\begin{abstract}
The indiscriminate use of chemical fertilizers leads to various types of pollutions. Now there is urgent need to use biofertilizer for sustainable agricultural development. In present paper the study was made to see the manurial value of sludge and digester effluent. This is mainly used as a biofertilizer. The chemical analysis of digester effluent and sludge produced after biomethanation were done by using standard methods. The waste generated during biogas production shows N, P, K amount $0.363,0.41$, and $16.87 \%$ in effluent and $0.56,0,01$ and 0,687\% in sludge. Micronutrients were also reported in considerable amount. Effluent and sludge has good manurial value and it can effectively supplement other fertilizers. There was $71 \%$ BOD and $74 \%$ COD reduction in effluent and sludge, which helps in reduction of the pollution potential of wastes.
\end{abstract}

Key words: Biomethanation, pollution, manurial value, biofertilizer

\section{Introduction}

The spent slurry as it comes out of the biogas digester contains about $90-94 \%$ moisture and $6-10 \%$ solid material (sludge) is composed mainly of organic matter (humus) and plant nutrients. It can directly fertilize crops without the adverse effect. The liquid effluent is also rich in nutrients.

The effluent which comes out of a biogas digester is quite low in pollution and can be disposed off after providing suitable treatment or dilution. The decomposition of organic matter in nature leads to uncontrolled production of methane gas, which is second most important green house gas having 25 times higher global warming potential compared to $\mathrm{CO}_{2}$ in a time span of 100 years Cassada, (1990). Stewart et al. (1984) noted that silage crop Leucerene (Medicago sativa) is best additive to cow dung to increase biogas production and its methane content.

Farmyard manure is the oldest organic manure used by man ever since he involved in farming. It has stood the test of time and is still very popular among the poor and marginal farmers on average welldecomposed farmyard manure contain $0.5 \%$ nitrogen, $0.2 \%$ phosphorus and $0.5 \%$ potash. Based on this analysis, an average dressing of 25 tones of FYM per hectare supplies $112 \mathrm{~kg}$ of nitrogen, $56 \mathrm{~kg}$ of phosphorus and $112 \mathrm{~kg}$ of potash the ability of the farmyard manure to supply humus to the soil makes its use unavoidable. To build up a desired level of humus, organic manures must be applied to the field. Unfortunately, the importance and value of this manure has not been sufficiently realized in this country.

Soil is a habitat of numerous organisms. They feed on organic matter applied to the soil. Application of manure is immediately followed by a marked increase in microbial population of the soil. A healthy microbial pollination is essential for the important bio-chemical changes taking place in the soil. The cycles that permit nutrients to flow from soil to plant are all interdependent and proceed only with the help of the living organisms that constitute the soil community. Their presence is essential for a healthy soil eco-system. Organic matter assists the micro-organisms to flourish and carry out necessary changes in the soil.

A microbial cell contains a C: N: P: S ratio of approximately 100: 10: 1: 1 Mitchell, (1974). C: N and C: $\mathrm{P}$ ratios of 25: 1 and 20: 1, respectively, have also been suggested as approximate for anaerobic digestion (Ghosh et al. 1978). Therefore, in order for growth to occur, these elements must be present and available.

The production of biogas can also serve as a means of recycling of organic matter; the organic matter is converted into energy and nutrients (manure) where the latter goes back to the plants and energy can be used for various purposes. Production of biogas from organic matter will not only cater to the needs of energy but may also serve as means of pollution control and maintaining environmental balance. As a large number of industrial wastes with high organic contents can also be converted in biogas by use of anaerobic degradation, this can be used as a means of waste water treatment, where biogas can be obtained as a byproduct.

The effluent after digestion formed superior quality manure. Almost $70 \%$ of population of India lives in villages, where the plant and animal biomass in the form of cattle dung, dry leaves, agricultural residues and plant weed is available in plenty, which can easily be converted into biogas. And waste generated after biogas production as fertilizer. In the present paper the study was carried to study whether weed and distillery waste can be used for biogas production and wastes generated has a Manurial value. 


\section{Materials}

\section{Material And Methods}

1) Weed material - Ipomoea carnea

Weed plants were collected from Satara and nearby areas from the habitats like road and rail side, agricultural land, and pond and river waters. The plants were studied botanically, identified and preserved in the form of herbarium specimens with proper labeling.

2) Distillery waste

3) Slurry of ongoing cattle dung based biogas plant

4) 100-L capacity Biogas digester

5) Chemical reagents

\section{Methods}

1) Collection, preparation and storage of weed material

The leaves and twigs of weed, free of soil, were collected from selected sites / localities

In sterile plastic bags using sterile hand gloves and a knife.. The pieces were powdered in

a mixer, dried at room temperature $\left(30^{\circ} \mathrm{C}-35^{\circ} \mathrm{C}\right)$ for $96 \mathrm{hrs}$, The dried biomass was soaked in water or dilute alkali to form a slurry at the time of further use.

2) Collection and storage of waste samples the distillery waste was collected as fresh Composite sample in

disinfected plastic carboys of 5-50-L capacity and stored at refrigeration till further use.

4) Chemical analysis of weed biomass, agro wastes and digester effluents - Chemical Reagents, apparatus and methods used for chemical analyses of weed materials, agro based and industrial wastes (distillery, sugar, dairy and farmhouse wastes), digester effluents and sludges were as per APHA (1985), Trivedy and Goel (1984) and AOAC (1990).

5) Scale-up studies The scale-up studies were performed with 25,50 and 100-L capacity digesters using the parameters of retention time ( 25 days) and $\mathrm{pH}(7.5)$ while temperatures at 25,50 and $100-\mathrm{L}$ were 33,35 and $38^{0} \mathrm{C}$, respectively. The admixture of weed biomass-distillery waste with $\mathrm{pH} 7.5$ was added at daily loading amounts of 1,000,2,000 and 4,000 $\mathrm{kg}$ for 25, 50 and 100-L capacity digesters, respectively. The initial seeding material was that obtained from 4-L digesters, which contained exclusive fermenting admixture of weed biomass-distillery waste, which was used for 25-L digester from which it was later used as initial seeding for 50 -L digester. Ultimately the fermenting slurry from 50-L digester was used as initial seeding for $100-\mathrm{L}$ digester. The biogas volumes were recorded daily for $25-\mathrm{L}, 50-\mathrm{L}$ and $100-\mathrm{L}$ digesters, while percent methane contents were estimated twice a week.

6) Manurial value The sludge and effluent from 100-L capacity scale-up level digester were subjected to their N, $\mathrm{P}, \mathrm{K}$, micro and macro elements determination as per method described earlier and the manurial value were studied in comparison with super phosphate, urea and with reference to Chandra, (1987).

7) Pollution abatement study The reduction in pollution potential of distillery waste and weed biomass (Ipomoea) admixture after biomethanation, was studied with reference to organic content, in terms of \% reductions in COD and BOD

\section{Results}

1) Chemical Characteristics of Ipomoea showed that Organic matter $\mathrm{mg} / \mathrm{kg} 66,540$, Carbon, $\mathrm{mg} / \mathrm{kg} 49,800$, Nitrogen, mg/kg 2980, C : N ratio16.7, BOD, mg/kg45,950, Phosphorus, mg $/ \mathrm{kg} 560$, Potassium, mg/kg2800, Calcium, mg/kg880, Magnesium, mg/kg990, Iron, ppm 190 Manganese, ppm, 75, Zinc, ppm 49, Copper, ppm5, $\mathrm{BOD}: \mathrm{N}: \mathrm{P}$ ratio120:7.7:1.4

2) Chemical characteristics of batch process distillery waste showed that it was acidic with $\mathrm{pH}$ range of 4.2-4.5, The COD and BOD contents were 1,12,000 and 41,290 mg/kg, respectively. The C: $\mathrm{N}$ ratio was 19.16 1981), while BOD:N:P (120:4.5:2.77). Total volatile solids (TVS) content of 64,000 mg/kg. The potassium content of distillery waste was fairly high i.e., $11,200 \mathrm{mg} / \mathrm{kg}$ as compared to other elements like calcium, magnesium, iron, manganese, zinc and copper, which were low at the level of 720, 229, 195, 0.5, 0.4 and $0.2 \mathrm{mg} / \mathrm{kg}$, respectively

Table :1 Chemical analysis of effluent and sludge

\begin{tabular}{|c|l|l|l|}
\hline Sr. NO & Parameters & Effluent & Sludge \\
\hline 1 & PH & 7.2 & 7.2 \\
\hline 2 & Water \% & 87.78 & 83.02 \\
\hline 3 & Total solids\% & 12.22 & 16.99 \\
\hline 4 & Total volatile solids\% & 96.65 & 89.14 \\
\hline 5 & Ash\% & 3.35 & 10.86 \\
\hline 6 & Nitrogen\% & 0.363 & 0.56 \\
\hline 7 & Phosphorus(as P2O5)\% & 0.41 & 0.01 \\
\hline 8 & Potassium( asK2O)\% & 16.87 & 0.687 \\
\hline & Microelement Analysis & & \\
\hline
\end{tabular}


Manurial Value and Pollution Abetment of Effluent and Sludge from Biogas Digester Run on ....

\begin{tabular}{|l|l|l|l|}
\hline 1 & Iron,ppm & 1.67 & 74.63 \\
\hline 2 & Manganese,ppm & 0.01 & 395.32 \\
\hline 3 & Zinc,ppm & 0.55 & 2.49 \\
\hline 4 & Copper,ppm & 0.10 & 1.493 \\
\hline
\end{tabular}

3) Chemical analysis of effluent and sludge from 100-L biogas digester (Scale-up studies) run on Ipomoea weed material admixed with distillery waste shown in Table :1

4) Pollution abetment study - Table: 2 shows the detail of Pollution abetment study at 100 L level, 25 days retention time, $37-38^{\circ} \mathrm{C}$ temperature with daily influent admixture loading of $4 \mathrm{~kg}$.

Table: 2. Pollution abetment stud

\begin{tabular}{|l|l|l|}
\hline \multicolumn{2}{|c|}{ Table: 2. Pollution abetment stud } \\
\hline 1 & Description & value \\
\hline 2 & Digester capacity & $100-\mathrm{L}$ \\
\hline 3 & Retention time & 25 days \\
\hline 4 & Digester Temperature & $37-38 \mathrm{C}$ \\
\hline & Daily influent loading & $4 \mathrm{~kg}$ \\
\hline & Total COD & $6,70,132 \mathrm{mg}$ \\
\hline & Total BOD & $3,46,133 \mathrm{mg}$ \\
\hline & Total TVS & $2,83,120 \mathrm{mg}$ \\
\hline 5 & 4 kg admixture contains & \\
\hline & Distillery waste & $2667 \mathrm{~mL}$ \\
\hline & Ipomoea biomass & $1000 \mathrm{gm}$ \\
\hline 6 & Average volume of biogas produced/kg/day & 40 \\
\hline & By Ipomoea weed & $36.63 \%$ \\
\hline & By Distillery waste & $63.37 \%$ \\
\hline 7 & Influent character & \\
\hline & PH & 7.5 \\
\hline & COD & $1,67,533 \mathrm{mg} / \mathrm{kg}$ \\
\hline & BOD & $86,533 \mathrm{mg} / \mathrm{kg}$ \\
\hline & Effluent character & \\
\hline & PH & 7.2 \\
\hline & COD & $48,585 \mathrm{mg} / \mathrm{kg}$ \\
\hline & BOD & $19,037 \mathrm{mg} / \mathrm{kg}$ \\
\hline & $\%$ COD reduction & 71 \\
\hline & $\%$ BOD reduction & 78 \\
\hline & $\%$ Methane content & 62.32 \\
\hline &
\end{tabular}

\section{Discussion}

The two kinds of substrates were used in the present studies to tap their biomethanation potential and utilization of sludge and effluent as biofertilizer The characteristics of batch process distillery waste showed that it was acidic with $\mathrm{pH}$ range of 4.2-4.5, which was unsuitable for biomethanation as for biomethanation neutral to slightly alkaline $\mathrm{pH}$ is required. The COD and BOD contents were $1,12,000$ and $41,290 \mathrm{mg} / \mathrm{kg}$, respectively. The C:N ratio was 19.16 indicating its suitability for biomethanation Hills, (1979); Hobson et al., (1981), while BOD:N:P (120:4.5:2.77) ratio showed slight deficiency of nitrogen as compared to BOD and phosphorus Hills, (1979); Hobson et al., (1981). Total volatile solids (TVS) content of $64,000 \mathrm{mg} / \mathrm{kg}$ further showed its suitability for biomethanation.

Agro based industrial wastes like distillery IS available in large quantities in the Satara region. The hundreds of cubic meters of wastes are produced daily in these industries. This waste possess huge pollution potential with respect to their volumes and organic content. This waste, if disposed into water bodies and land or soil environments without prior treatment, can cause severe environmental problems. The organic content of these wastes hinted at their utilization to the processes like biomethanation along with weed biomass to generate energy in the form of biogas, and sludge and effluents as supplement to manure and fertilizer. Further, the process will cause reduction in environmental pollution, in general

In a present study $1 \mathrm{M}^{3}$ digester was used with daily loading $40 \mathrm{~kg}$ admixture. The amount of effluent and sludge coming out per day also $40 \mathrm{~kg} /$ day, annually $14400 \mathrm{~kg}$ slurry will be produced. The sludge settled upon standing 1 hour constitute $39 \%$ volume, while supernatant constitute $61 \%$ of volume, hence the total amount of sludge produced annually is $5616 \mathrm{~kg}$, while annual effluent generation is $8784 \mathrm{~kg}$. The cost of sludge and effluent was taken on the basis of market price of nitrogen, phosphorus and potassium. 1) urea- $46 \%$, nitrogen $@$ Rs 132/ 50kg therefore $\mathrm{N}_{2}=$ Rs. 5.74/kg 2) super phosphate - 16\%. $\mathrm{P}_{2} \mathrm{O}_{5} @$ Rs.135/kg therefore $\mathrm{P}_{2} \mathrm{O}_{5}=$ Rs.8.44/kg 3) Murate of potash - 30\% $\mathrm{K}_{2} \mathrm{O} @$ Rs. 230/kg. Therefore $\mathrm{K}_{2} \mathrm{O}$ - Rs.15.33/kg.

Revenue from effluent, sludge /year shown in Table:3. N P K content of effluent and sludge were $0.363,0.41,16.87 \%$ and $0.56,0.01,0.687 \%$ respectively. The total NPK generated annually from effluent and sludge were $31.89,36.00,1481 \mathrm{~kg}$ and $31.45,0.56,38.58 \mathrm{~kg}$ respectively. This cost does not include cost of organic material, fibers, humus, return from crops and micronutrients present in it. 
Table:3 Revenue from effluent, sludge /year

\begin{tabular}{|c|c|c|}
\hline A) & Effluent & Rs. \\
\hline 1) & Nitrogen@Rs 5.74/kg x 31.89/ & 183.00 \\
\hline 2) & Phosphorus@Rs 8.44/kg x 36.00 & 303.00 \\
\hline 3) & Potassium@Rs15.83/kgx1481.90 & $22,703,70$ \\
\hline B) & Sludge & \\
\hline 1) & Nitrogen@Rs 5.74/kg x 31.45 & 180 \\
\hline 2) & Phosphorus@ Rs 8.44/kg x oo.56 & 4.73 \\
\hline \multirow[t]{2}{*}{ 3) } & Potassium@Rs 15.83/kg x 38.58 & 591.40 \\
\hline & Total of Effluent + Sludge for $14,400 \mathrm{~kg}$ digester slurry & $23,967.13$ \\
\hline
\end{tabular}

The $14,400 \mathrm{~kg}$ slurry produced annually upon $40 \%$ drying generates $8,640 \mathrm{~kg}$ manure, which can be sold at Rs. 1,000/tone, i.e., it will generate Rs. 8,640/- revenue.The anaerobic digester effluent from biomethanation of admixture of Ipomoea biomass and distillery waste showed a good manurial potential. NPK values obtained for sludge and effluent were $0.56 \%, 0.01 \%, 0.687 \%$, and $0.363 \%, 0.41 \%, 16.87 \%$ respectively The chemical analysis of digester effluent for NPK and micronutrients showed that the sludge and remaining effluent possessed good manurial value to be used as a supplement to fertilizers in agriculture

The percent COD and BOD reductions in case of admixture of Ipomoea biomass and distillery waste after biomethanation at 100 -L scale up studies were averaged to 71.0 and $78.0 \%$ indicating significant reductions in the pollution potential of substrates used.COD and BOD reductions in admixture of Ipomoea biomass and distillery waste after biomethanation were $71 \%$ and $78 \%$, which indicated that the biomethanation process can significantly remove the organic and pollution load of weed biomass and the distillery waste.

\section{Summary And Conclusion}

1) Survey, selection and collection of common troublesome weed, distillery waste from Satara region for biomethanation studies and collection of data in light of their availability, pollution and environmental aspects.

2) Physico - chemical characteristics of weed biomass and wastes for COD, BOD, TOC, total nitrogen, $\mathrm{pH}, \mathrm{TS}$, TVS, color, odor, C:N, BOD:N:P ratios, microelements like phosphorus, potassium, calcium, magnesium, iron, manganese, zinc and copper.

3)The anaerobic digester effluent from biomethanation of admixture of Ipomoea biomass and distillery waste showed a good manurial potential. NPK values obtained for sludge and effluent were $0.56 \%, 0.01 \%, 0.687 \%$, and $0.363 \%, 0.41 \%, 16.87 \%$ respectively.

4) Pollution studies The percent COD and BOD reductions in case of admixture of Ipomoea biomass and distillery waste after biomethanation at 100-L scale up studies were averaged to 71.0 and $78.0 \%$ indicating significant reductions in the pollution potential of substrates used.However some other additional weed biomasses and organic wastes available should also be tried and studied for their disposal through biomethanation

5) Effective recycling of waste with good quality biofertilizer and reduction of pollution load can be achieved which helps in sustainable development.

\section{References}

[1]. AOAC (1990). Official Methods of Analysis of Association of Official Agricultural Chemists, $15^{\text {th }}$ edition, published by A.O.A.C. INC, Suite 400, 2200, Wilson Bodevard Arlington, Virginia, 22201, USA.

[2]. APHA (1985). Standard methods for examination of water and waste Water, Americal Public Health Association, $15^{\text {th }}$ edition.

[3]. Chandra, P. (1987). Projects, Preparation, Appraisal Budgeting and Implementation, $3^{\text {rd }}$ edition, Tata McGraw Hill, Publ. Co. Ltd., New Delhi pp. 1-570.

[4]. Cassada, M. E. (1990). Methane emission from different animal waste management systems. Safety L. M. Journal.

[5]. Chandra, P. (1987). Projects, Preparation, Appraisal Budgeting and Implementation, $3^{\text {rd }}$ edition, Tata McGraw Hill, Publ. Co. Ltd., New Delhi pp. 1-570.

[6]. Ghosh, S. et al. (1978). Anaerobic Process - Literature Review. J. Water Poll. Control Fed., 50 (10).

[7]. Hill, D. J. and Roberts, D. W. (1979). Agri wastes, 1: 267.

[8]. Hobson P. N., Bousfield, S. and Summens (1981). Methane production from agricultural and domestic waste. Applied Science Publishers Ltd., London, 1981.

[9]. Mitchell, R. (1974). Introduction to Environmental Microbiology, Englewood Clifts, NJ, Prentice Hall, Inc.

[10]. Trivedy, R. K. and Goel, P. K. (1984). Chemical and Biological Methods for Water Pollution Studies. Environmental Publications, Karad.

[11]. Stewart, D. T., Boque, M. T. and Bodger, D. M. (1984). Biogas production from crops and organic wastes. N2. J. Sci., 27 (3): $285-$ 298. 